\title{
Difficulties and Expectations of Foreign Nursing Students in the Clinic
}

\author{
Serap Parlar Kiliç ${ }^{1}$, Gülendam Karadağ ${ }^{2 *}$, Nermin Kiliç ${ }^{3}$ and Cihat Demirel ${ }^{3}$ \\ ${ }^{1}$ Inönü University, Turkey \\ ${ }^{2}$ Dokuz Eylül University, Turkey \\ ${ }^{3}$ Firat University, Turkey \\ "Correspondence: gkaradag71@gmail.com
}

\begin{abstract}
The purpose of this study was to determine the difficulties and expectations of foreign nursing students during their nursing practice in the clinic. This qualitative study was conducted with six foreign students studying in the department of nursing at a university in Turkey. The data were collected by using a focus group interview method, and two focus group interviews were held. Two main themes, namely, difficulties during the nursing practices in the clinic and expectations, and related subthemes were determined. All the students described the difficulties they experienced regarding nursing practices in the hospital. The foreign and migrant students participating in this study experienced difficulties regarding communication, applying treatments, providing training to patients, and applying care interventions to patients during nursing practice in the clinic; they also had expectations from nursing educators to spend sufficient time with them and be present with them in the clinic, and from nurses to assist them for adaptation to the clinic.
\end{abstract}

Keywords: difficulties, expectations, nursing, foreign students, clinic

\section{Introduction}

Rapid change and development are occurring in almost every area, and the areas of technology, education, and transportation are among the foremost areas worldwide. The world is becoming more and more multidimensional, both culturally and linguistically as people move from one country to another across borders (Narouz, 2018). Due to globalization and impacts from the common market, rapid changes have been observed in the field of education. A significant portion of this education market comprises foreign student exchanges (Kıroğlu, Kesten, \& Elma 2010). International student mobility has a positive effect on the quality of education by increasing the cooperation and solidarity between countries and cultures, contributing to the promotion of the countries where they are

Received December 1, 2019; revised April 25, 2020; September 18, 2020; accepted September 30, 2020; electronically published March 2, 2021 
educated, and securing accreditation and standards to attract international students (OECD, 2016). Looking across the world, the number of international students, which was around 800,000 in 1975, reached six million in 2014, and eight million by 2020 (Kocabıyık, Donat, \& Güvendir, 2019).

According to the data of the Higher Education Council, foreign nationals studying in academic universities in Turkey in 2017-2018 was 125,138. The leading countries sending international students are Syrian (20,701 students), Azerbaijan (17,088 students), and Turkmenistan (12,247 students). Based on the '2016 Turkey Migration Report' prepared by the Directorate General of Migration Management, Ministry of Internal Affairs, the total number of foreign students in universities in Turkey was 103,727 (Turkish Migration Report, 2017; Doğru, 2020).

\section{Literature Review}

Students of foreign nationalities who study in Turkey or study as migrants and reside in Turkey encounter difficulties as a result of living in a different country. Most of these are based on difficulties caused by the adaptation process to a new and different culture (Tuzcu \& Bademli, 2014). International students in Turkey face many challenges such as culture diversity, education system, language, environment customs and traditions (Narouz, 2018). Foreign students must adapt to the culture and way of life of a host country to succeed in their academic and social life (Rienties \& Tempelaar, 2013; Tuzcu, 2014). In a study by Alagöz and Geçkil, (2017), they found that students reported difficulties related to language, communication, adaptation to a foreign environment, conflicts in social and moral values, feeling alienated, and adapting to a new education system. Having a different educational system, living in a different culture, not being able to speak Turkish sufficiently, and economic problems make adaptation for foreign students coming to Turkey for higher education difficult in terms of adaptation to the university and their circle and affect their academic success (Özçetin, 2013). According to the research results of Şahin and Demirtaş (2014) and Enterieva and Sezgin (2016), foreign students continue to have several types of academic, social and educational support service problems (Enterieva and Sezgin 2016). As internationalization is an important concept in higher education, faculty and administration department should play an important role to assess the international students' needs, challenges and culture shock in order to be able to plan for a supportive environment to provide different means of encounter and support of the international students and to include a social integration program in the curriculum (Narouz, 2018).

\section{Foreign Student Nurses and Clinical Teaching}

Clinical teaching is the means by which student nurses learn to apply the theory of nursing and to facilitate integration of theoretical knowledge and practical skills in the clinical setting which becomes 
the art and science of nursing (Tiwaken et al. 2015). Care is the principle topic for nurses with a significant role in the health team. The purpose of nursing care is to aid and accompany individuals unable to carry out special functions regarding their physical, psychological, and psychosocial needs. The health problems of individuals from different cultures, their perceptions of these problems, and their aid expectations may differ (Seviğ \& Tanrıverdi, 2012). Quality individual care may be provided by considering factors related to the culture, beliefs, customs, and values of patients and their families. Nurses play crucial roles in patient care and must respect cultural values of the patients while providing care and provide the required nursing care in that sense to enhance care quality (Foronda, 2008; MaierLorentz, 2008; Stimpson \& Martin, 2005).

Another element that enhances nursing care quality is the adaptation of foreign nurses into their clinical setting or the nursing education of the nursing students. Clinical education is the main part of education for nursing and other health programs. Learning in clinical practice provides up to half of the educational experience for students taking in Nursing (Tiwaken et al., 2015). Students in the clinic practice are expected to achieve proficiency in expressing the values, attitudes, knowledge, and skills related to nursing education. This education also aims to increase critical thinking, analysis, psychomotor, communication, and management skills and confidence while implementing nursing. However, the success of clinic education is affected by many factors (Shawwa et al., 2015). One factor is when a student changes to a new educational environment. A limited number of studies have investigated both the language and education problems of foreign nursing students coming to Turkey to study. Based on these data, considered that determining the difficulties experienced by foreign and migrant students studying in the department of nursing regarding speaking a different language, experiencing cultural differences, being obliged to provide care in the hospital, and being the nurses of the future during clinic practice and their expectations and who will be the nurses of the future responsible for providing care in the hospital shall be a predictor for all patients receiving care in Turkey and other foreign patients continuing to receive the care to plan the nursing management. These data would be a guide for curriculum of foreign nursing students. Thus, the curricula should be organized by being aware of the difficulties and expectations of these students during their education and estimated to increase their motivation and sustain their education in a healthy and peaceful sense because of reasons such as positive nursing care and practices of the students. Therefore, this study, aimed to determine the difficulties of foreign students studying in the department of nursing in nursing practices in the clinic and their expectations. 
The purpose of this study was to reveal the difficulties of foreign students studying in nursing departments in Turkey during their clinic practice, and their expectations.

\section{Methodology}

\section{Design and Sample}

Qualitative studies are a research method that have been used frequently in the fields of health and nursing. Qualitative research is helpful in determining the needs, preferences and motivations of healthcare professionals, students and patients (Başkale, 2016). The data collection method of the research was shaped based on the relevant literature (Erdoğan et al., 2014). The descriptive design of the study was based on qualitative content analysis using an inductive approach and involved discovery and description (Arlı, 2013; Karataş, 2015). Qualitative research is a flexible design that does not have a rule set for the sample size, and the sample size is decided in line with the research question and purpose (Erdoğan, Nahcivan, \& Esin 2014). This approach emphasizes the use of meaning and the understanding of experiences of students. This study was conducted with six foreign students who were studying in the department of nursing at a university in the education year 2016/2017 and who met research inclusion criteria. In the study, a balanced number of male and female students and students from different countries was used to determine the difficulties and expectations of the students while conducting nursing practices in the clinic. There was a total of thirteen foreign students studying in the nursing department. The inclusion criteria for the participants in the study were as follows: 1) student in the department of nursing; 2) a foreign student; 3) a student participating in clinical practice in the hospital (therefore, first-year students were not included); 4) able to understand and speak Turkish; and 5) volunteered to participate in the study. All other students were excluded (three first-year students not participating in clinical practice; two students not able to understand and speak Turkish; two students did not volunteer to participate in the study).

\section{Data Collection}

The data were collected by using a focus group interview method, and two focus group interviews were held. The focus group is defined as a group of individuals with specific characteristics that focus on discussions on a particular topic or topic. A focus group interview provides a setting for the relatively homogeneous group to reflect on the questions asked by the interviewer. (Dilshad \& Latif, 2013). Focus group interviews enable a limited number of participants (six to eight) to discuss their feelings, ideas, impressions, expectations, and attitudes in an interactive manner regarding a particular topic and allow thorough data collection (AkıncI, 2015; Arlı, 2013). The focus group interviews were conducted in the schools of these students. Students were invited by the researchers to be informed 
about the research. The seating order in the room was arranged so the participants and researchers could see each other. Preliminary interviews are a part of the focus group interview process. In the preliminary interviews held before the focus group interviews, the students were informed about 'what a focus group was', 'that voice recorder would be used during the interviews', and the 'study', and their consent was requested. At the preliminary interviews, students received forms on which they wrote down their sociodemographic information. Next, in-depth interview questions were asked. Because the students might have difficulties in understanding and speaking Turkish, an attempt was made to ask the questions at the simple and clearest, and sufficient time was provided to prevent them from providing superficial responses. One of the researchers asked the interview questions and acted as the moderator during the interview, another researcher recorded the interview uninterrupted with the voice recording device, and a third researcher took short notes on the responses of the students. The duration of the interviews was on average 35 to 45 minutes, and therapeutic communication techniques were used. It was stated that the names of the participants would be kept confidential and interviews were conducted by giving a code name to each.

\section{Research Questions for the Interview}

The focus group interviews were used as a data collection tool and questions asked to the participants. A questionnaire was developed by the researchers to elicit the sociodemographic data of the students (age, gender, nationality, grade), and a semi-structured interview form comprising openended questions including the difficulties they experienced (seven questions) and their expectations (five questions) concerning the nursing practices in the clinic were used to collect the data (Table 1).

\section{Table 1}

\section{Questions to Be Answered in the Study}

1. Difficulties the students experienced during nurses' practices in the clinic:

What are difficulties you have experienced in nursing practices due to cultural differences?

What are difficulties you have experienced in nursing practices regarding communication or due to the language difference?

What are difficulties you have experienced regarding the communication within the team?

What are difficulties you have experienced regarding the care giving?

What are difficulties you have experienced regarding the application of treatments?

What are difficulties you have experienced regarding the providing of patient training to patients? 
What are difficulties you have experienced while exchanging information with your classmates and during the process of practice?

2. Expectations of the students concerning the difficulties they experienced during the nursing practices in the clinic:

What are your expectations from nursing educators?

What are your expectations from the nurses working in the hospitals?

What are your expectations due to cultural differences? (Have you ever had any problem with any of the nurses or educators due to cultural differences or if so, how have you resolved this problem?)

What are your expectations regarding communication or due to language problem? (Have you had a communication problem among your nurses and educators due to language problem or how have you resolved this communication problem?)

What are your expectations concerning psychological support?

\section{Data Analysis}

To analyse the data obtained from the focus group interviews, the voice-recorded data were recorded as raw data by the researcher without making changes on the computer directly after the interview. The demographic characteristics of the students were analysed through descriptive statistics, and the qualitative data were assessed by using inductive content analysis. Content analysis was implemented in six steps. In the first phase, the voice recording was deciphered by the researcher on the same day as the interviews, and they were recorded by assigning them a code number. In the second phase, after providing the written documentation of the recorded data, they were evaluated independently by three researchers, and the codes likely to be interpreted from each sentence were created. In the third phase, the important sections of the participant statements were chosen to generate the first codes and to assess the reliability of the results during the coding process. In the fourth phase, the researchers noticed themes among the codes. The subcategories were analysed based on the dimensions of both the similarities and the differences before the division (of data/texts) into categories (Kocabıyık, 2016). In the fifth phase, the themes were determined and named during the course of analysing the responses of the students to every question from the semi-structured interview in the fourth and fifth phases (Clarke \& Braun, 2013; Tong et al. 2007). A software program was not used to code qualitative data (Tong et al. 2007). In the sixth and last phase, all the obtained data were analysed through thematic analysis and put into a report after their interpretation. 


\section{Ethical Considerations}

Approval from the Non-invasive Trials Ethics Committee of a University (04.05.2017/195384) and written permission from Dean's Office of Faculty of Health Sciences a University was obtained. The students were informed about the purpose and the content of the study, and they provided verbal consent for their participation.

\section{Results}

\section{Sample Characteristics}

The average age of the participants was 21.5 y (SD 1.87, range: 19 to 23 y). Notably, of all the students 50 percent were female, 16.7 percent were fourth-year students, 50 percent were third-year students, and 33.3 percent were second-year students. Although 33.3 percent of the students resided in the dormitory, 66.7 percent resided off-campus with a housemate. Two students were Nigerian, two were Syrian, one was from Azerbaijan, and another student was from Tajikistan. All students received Turkish language education for a certain period of time at their university before they began their education in the nursing department.

\section{Themes and Subthemes}

In this study, two main themes and subthemes were created. Table 2 shows the themes and the subthemes created by using the data of the students.

\section{Table 2}

Themes and Subthemes created based on the students' statements

\begin{tabular}{l|ll}
\hline Themes & \multicolumn{1}{c}{ Subthemes } \\
\hline Difficulties & $\bullet$ & Difficulties regarding cultural differences \\
$\bullet$ & Difficulties regarding communication \\
$\bullet$ & Difficulties regarding treatment application \\
& clinic & Difficulties regarding providing training to the patients in the \\
& patients \\
\hline Expectations & - Expectations regarding cultural differences \\
\hline & - Expectations regarding communication \\
\hline
\end{tabular}


- Expectations regarding clinic nurses

\section{Theme 1: Difficulties}

All the students described the difficulties they experienced regarding nursing practices in the hospital. The majority of difficulties experienced by the students was in regards to communication, and the other most-mentioned difficulties were cultural differences, application of treatments, training patients, and application of care interventions for patients.

\section{Difficulties Regarding Cultural Differences}

Most of the students who were foreigners and migrants, did not experience problems regarding cultural differences. The majority of students stated that they were welcomed, and especially by patients. However, some students did not want to provide care for patients of the opposite sex because of cultural reasons. Student views regarding this topic were as follows: "I did not experience difficulty because our cultures are not very different. Our cultures are similar (Because the patient was Azerbaijani)" (Student 1).

While implementing the course of delivery, I could not ask the patients questions I felt hesitant about asking. This is how I am. The situation would have been better if I had been there with a female friend. Whenever I went to see a female patient, my female friend would ask the questions I felt embarrassed about. She would ask, but I would not be able to. I used to feel disturbed when I thought that the patient would hesitate. (Student 2)

\section{Difficulties Regarding Communication}

The analysis of the opinions of the students demonstrated that they could not articulate exactly what they wanted to express and could not establish sufficient communication because they thought that the nurses and patients would not understand what they said. Concerning this topic, the students' views were as follows: "I formulate my ideas while communicating. However, while speaking, I put these ideas into words but I have trouble because I am unable to express the exact meaning..." (Student 1).

The nurses in the clinic sometimes assign me patients for blood draws, but some patients say demotivating things like 'this is a foreigner, he does not even speak Turkish, how will he take blood from me?' as I am about to leave, and this makes me sad. (Student 2) Nurses speak too fast during treatments. We do not understand when they pronounce the names of the drugs quickly. My friends understand immediately because they are Turkish. 
However, we find have to request several repetitions to understand. Notably, we do not execute the treatment without understanding fully. (Student 5)

Some patients in Elazığ city do not speak Turkish. They speak languages such as Kurdish or Zazaki. Hence, we do not understand these patients, and they do not understand us. Therefore, miscommunication occurs. (Student 6)

\section{Difficulties Regarding Treatment Application}

The views of foreign and migrant students on treatment applications varied. Most of the students stated that they experienced difficulty in applying treatments, and other students apparently received assistance during the application of treatment because they were foreigners. The students' related views were as follows:

During the treatment, the nurses shout out the name of the medications and say "take this and apply this on the patient besides the window", sending me by the patient. They are unable to explain. Therefore, I feel compelled to say "let me ask the nurse." (Student 3) Some patients and nurses said 'these students came from other countries, we should ensure they do not leave the country without learning' during the treatment, and we carried out the treatment for this reason. This was nice. Sometimes there would be things we did not know about. Our Turkish friends or other friends would assist us. (Student 4)

\section{Difficulties Regarding Providing Training to the Patients in the Clinic}

The majority of the foreign and migrant students did not mention significant difficulties in providing training to patients. The views of students stating that they experienced difficulties were as follows: "We speak slower than our other friends while speaking Turkish because we are foreigners. This causes problems for us" (Student 3).

I have problems when our lecturers are angry during the course. My lecturer would always look at and inspect me whenever there was a problem, thinking that I may not have understood some of the rules (e.g. putting my telephone into silent mode during the course), even though I did not do anything. This disturbs me. This prevented me from understanding the subject and providing training to patients. (Student 6)

\section{Difficulties in the Application of Care Interventions for Patients}

Although a very small number of foreign and migrant students stated that they did not experience problems regarding the application of care interventions for the patients, most of the students stated that they experienced difficulties in providing care to the opposite sex. The views of a student regarding these concerns were as follows: 
Some male patients did not want me to provide care for them. For instance, whenever I wanted to change the urine drainage bag, some patients did not accept me because I was female and asked for another person. They felt shy. This is why I provided care to only female patients. (Student 6)

\section{Theme 2: Expectations}

The students identified their expectations regarding the difficulties they experienced during the nursing practices in the clinic, the clinic nurses, and the nursing educators.

\section{Expectations Regarding Cultural Differences}

The foreign and migrant students expressed their views regarding their expectations of cultural differences as follows:

For instance, nurses provide us a list and ask us to read the names aloud to patients if we would provide nutrition training to the patients. In this case, no problem occurs. However, when patients ask us questions, we are unable to tell them anything concerning nutrition because our culture is different. Then, I generally receive support from friends who know about the issue. In other words, especially when we are performing a procedure on a patient or providing training to the patient, one of our masters or someone being with us encourages us. (Student 4) During clinic practices, foreigners are misunderstood culturally because they think we may not know some things. Of course, that situation changes over time. However, individuals should still raise awareness on this issue part by the profession. (Student 6)

\section{Expectations Regarding Communication}

The foreign and migrant students asserted their expectations on communication as follows: "I asked my friends rather than my lecturers about the language I did not understand because I feel closer to my friends. This is better" (Student 5). "There may be meetings organized at school. They may talk to us. Moreover, language instructors may participate in such meetings and may contribute to our language knowledge" (Student 6).

\section{Expectations from Nursing Educators}

The foreign and migrant students reported expectations of nursing educators spending sufficient time for themselves and more frequently accompanying them in the clinic thinking that they may not have understood. Regarding this topic, the student views were as follows:

For patient visits, our professors may spend more time with the foreign students. In the lecture, that is not a big problem, but in the clinic, it may be bad for the patient to carry out a wrong procedure without understanding when we perform a procedure during the clinical practice. (Student 3) 
Before starting in the hospital, we usually must have many practices in advance of each lecture. The nursing skill lab should be used more. Our motivation should be increased. Instead of being left alone during the practices, it would be better to have our teachers or friends who understand the topic with us. (Student 4)

\section{Expectations of Clinic Nurses}

The foreign and migrant students revealed that they did not have many expectations from clinic nurses, and their expectations were more oriented toward their adaptation to the clinic. Regarding this topic, the student views were as follows: Nurses may care with us more in subjects such as adaptation to the clinic and psychological support ..." (Student 2). "Nurses in charge of the clinic may assist us as well. They should train us regarding several topics. In other words, we would understand better if she said, for example, 'this is how you should give this medicine'"' (Student 5).

\section{Discussion}

The analysis of the study revealed two subthemes. (1) Students' difficulties regarding cultural differences, communication, treatment application, providing training to patients, and care intervention application to patients; and (2) students' expectations regarding adaptation in terms of communication, cultural differences, and from nurse educators and clinic nurses.

Effective communication with patients and health care workers is a key process in safe and quality health care. Patient and clinician relationships rely on good communication, resulting in improved patient satisfaction, adherence to medical recommendations, and better healthcare outcomes (Almutairi, 2015). Students' most frequently experienced problems were related to understanding the language and adapting to the culture and educational environment of the host society (Malekisanimaleki \& Altay, 2017). The majority of students experienced difficulties in communication during clinic practice. Language and communication problems were some of the most significant factors affecting foreigners requesting the provision of health services (Moyce et al., 2016). Speaking the same language while communicating is crucial during the treatment and care process. Communication problems are likely to occur based on the gaps in the use of common language and may influence and change the treatment and care approach. Problems occurred between speakers of the same language and would be more likely to occur in the process evaluation between individuals with different native languages (TaşCI, 2012). In the literature, the most notable barrier to nurses' and student nurses' provision of health care has been communication (Jirwe et al., 2010; Polat \& Akçan, 2016; Tuzcu \& Bademli, 2014;). In the studies conducted on midwifery and/or nursing students in Turkey, the most frequent problem experienced by students while providing care for patients during clinical practice was 
communication (Tanrıverdi et al. 2010; Tortumluoglu et al. 2007). Similarly, Tortumluoğlu et al. (2006) determined that students who experienced cultural diversity in patient care experienced these diversities while communicating with patients (44. 2 percent). In the study conducted by Lundberg et al. (2005) with fourth-year nursing students, most nursing students indicated that language and communication were the greatest problems when providing care to patients who were culturally diverse. A different study by Enterieva and Sezgin (2016) indicated problems regarding instruction language, and the most frequently encountered problem by the students was language. In studies conducted with foreign nurses, they had difficulties understanding medical terminology (Xu et al. 2008), speaking (Sherman \& Eggen-berger, 2008; Xu et al. 2008), interpreting the body language (Okougha \& Tilki, 2010), and establishing communication with patients and colleagues from different cultural backgrounds (Ma et al., 2010). Kesten et al. (2010) attempted to determine the problems regarding education and language of 15 foreign students studying at a university in Turkey and found that if students had a sufficient command of Turkish, this affected their reading comprehension skills negatively. Additionally, the students had problems expressing themselves, and the problems they experienced during their courses were associated with their insufficient level of Turkish.

This study observed that only students with a similar culture to theirs (Azerbaijani) had few problems in communication. It is reported that the most determining factor on this issue is the cultural and geographical distance-proximity of the country they went for the purpose of education (Kıroğlu et al., 2010). This occurred because students from Turkic Republics have historical and cultural connections and similarities with Turkey (Ertürk et al., 2004).

Communication difficulties led to distress and discomfort for the students. Language and communication barriers may have caused problems of emotional stress, disappointment and, embarrassment for foreign nurses (Moyce et al., 2016). Another study concluded that fear of communication caused foreign nurses to be shy about defending themselves and the patients (Allan \& Larsen, 2003). In study Small and Pretorius, (2010) demonstrated that nursing roles were observational rather than invasive because of the hesitation of the students.

This study determined that the student nurses experienced problems because of cultural differences and experienced difficulties in providing care due to gender differences. Lundberg et al. (2005) found that student nurses had problems related to gender while providing care to patients who were culturally different. Özçetin (2013) concluded that within the time the foreign students stayed in Turkey, the biggest challenge was cultural differences. Insufficient cultural awareness and difficulty with 
communication create barriers to understanding between nurses and patients from different cultures (Stimpson \& Martin, 2005).

One of the teachers' major responsibilities is to treat nursing students properly in the clinic, causing higher enthusiasm and motivation for learning as well as increasing their self-confidence (Jamshidi et al., 2016). In Turkey, clinical teaching in nursing education is generally performed by instructors in nursing schools, and clinical nurses working in hospitals (Dağ et al., 2019). The students expect their nursing educators to spend sufficient time with them, to be more present with them in the clinic because they might have problems understanding, and to have more frequent communication with them. Students must receive support and positive feedback from their educators because the role of motivation in learning is significant and the educator has a significant role in positively or negatively influencing the motivation of the students and their adaptation to the clinic (Günüşen \& Üstün, 2012). Especially notable is that the instructor as a role model and means of support for the student either in theoretical courses or fields of application positively strengthen the students learning of care behaviour and respect for their profession (Bahçecioğlu Turan et al., 2017). In Narouz's (2018) study, almost half of foreign students' difficulties to communicate with clinical instructors. Weaver (2006) stated that providing positive feedback to students increased their confidence and was encouraging. One means to create a positive learning environment for students is to have them comfortably express themselves. Educators are responsible for providing this opportunity to students (Günüşen \& Üstün, 2012). For this reason, educators must support students, particularly students who are foreign, and be present with them during nursing practices in the clinic as much as possible to increase their adaptation into the clinic and provide self-confidence.

This study also revealed that the students had expectations of the nurses in terms of their adaptation to the clinic and receiving support. In the clinics where practice occurs, nurses must be in charge to be a positive role model, be aware, be experienced and qualified in terms of occupational skills, and able to achieve the goals of the practice (Polat et al., 2018). The student must be guided, supported, and feel this support during the practices (Killam \& Carter, 2010). In study by Adamson (2018), the relationship with their mentor or preceptor was also important and students looked to them for reassurance and spoke of the value they placed on this support. Students from foreign countries experiencing difficulties in many factors such as cultural factors and communication may require this type of support a lot more.

\section{Conclusion}


It was observed that the foreign and migrant students participating in this study experienced difficulties regarding communication, applying treatments, providing training to patients, and applying care interventions to patients during nursing practice in the clinic; they also had expectations from nursing educators to spend sufficient time with them and be present with them in the clinic, and from nurses to assist them for adaptation to the clinic. The advisors have, of course, more tasks in particular to overcome such difficulties. The advisors and the nursing educators should provide academic guidance, orientation, and the required support to students from foreign countries in subjects such as adaptation, amalgamation, and establishing communication, especially during their first year.

In order to identify the difficulties experienced by foreign students in clinical practice, a broader sample of studies may be recommended. In addition, in this sense, it may be suggested conducting comprehensive quantitative studies with samples from other universities in Turkey, by considering variables such as their country, university, department, class, and gender.

\section{Author Note}

Serap PARLAR KILIÇ, RN, PhD. She works as a Professor at Inonu University Faculty of Nursing, Department of Internal Medicine Nursing, Malatya, Turkey. She works on chronic diseases, foreign students, and the elderly. Email: serap.parlar27@gmail.com

Gülendam KARADAĞ, RN, PhD. She works as an Associate Professor at Dokuz Eylül University Faculty of Nursing, Department of Public Health Nursing, İzmir, Turkey. She works on nursing education, nursing student, vulnerable groups. Email: gkaradag71@gmail.com

Nermin KILIÇ, Nurse, RN, Fırat University Institute of Health Sciences, Nursing Department, Turkey. She works as a nurse in Elazig State Hospital. She is a PhD student in the Internal Medicine Nursing program of İnönü University, Institute of Health Sciences. Email: nermin4423.kilic@gmail.com

Cihat DEMIREL, Nurse, RN, Firat University Institute of Health Sciences, Nursing Department, Turkey. He works as a nurse in Inönü University Hospital. He is a PhD student in the Internal Medicine Nursing program of İnönü University, Institute of Health Sciences. Email: cihatdemirel34@gmail.com 
Adamson, E. (2018). Culture, courage and compassion: Exploring the experience of student nurses on placement abroad. Journal of Compassionate Health Care, 5(5). https://doi.org/10.1186/s40639018-0048-4

Akıncı, Z. (2015). Meslek yüksekokullarında verilen turizm eğitiminin değerlendirilmesi: Bir odak grup calışması [The evaluation of tourism educationin vocational high schools: A focus group study]. Mediterranean Journal of Humanities, 5(1), 43-59. https://doi.org/10.13114/MJH.2015111367

Alagöz, S. B. \& Geçkil, E. (2017). Yabancı uyruklu üniversite öğrencilerinin sorunlarının incelenmesi: Konya İli örneği [Investigation of the problems of foreign university students: Konya Province examination]. Anatolian Nursing Health Sciences Journal, 20(4), 278-284.

Allan, H. \& Larsen, J. A. (2003). "We need respect": Experiences of internationally recruited nurses in the UK. https://www.rcn.org.uk/_data/assets/pdf_file/0008/78587/002061.pdf

Almutairi, K. M. (2015). Culture and language differences as a barrier to provision of quality care by the health workforce in Saudi Arabia. Saudi Medical Journal, 36(4), 425-431. https://doi.org/10.15537/smj.2015.4.10133

Arlı, E. (2013). Barınma yerinin üniversite öğrencilerinin kişisel ve sosyal gelişim ve akademik başarı üzerindeki etkilerinin odak grup görüşmesi ile incelenmesi. [Review of the effects of housing place on individual and social development and academic success of university students by focus group discussion]. Journal of Higher Education and Science, 3(2), 173-178.

Başkale, H. (2016). Nitel Araştırmalarda Geçerlik, Güvenirlik ve Örneklem Büyüklüğünün Belirlenmesi [Determination of validity, reliability and sample size in qualitative studies]. Dokuz Eylul University E- Jornal of Nursing Faculty, 9(1), 23-28

Clarke, V. \& Braun, V., (2013). Teaching thematic analysis: Overcoming challenges and developing strategies for effective learning. The Psychologist, 26(2), 120-123.

Dağ, Gülten S, Kılıç, Hülya Fırat, and Görgülü, Refia S, (2019). Difficulties in clinical nursing education: Views of nurse instructors'. International Archives of Nursing and Health Care, 5(1), 114. doi: $10.23937 / 2469-5823 / 1510114$.

Dilshad, R. M. \& Latif, M. I. (2013). Focus group interview as a tool for qualitative research: An analysis. Pakistan Journal of Social Sciences (PJSS), 33(2), 191-198.

Doğru, ME. (2020). Yükseköğretim Kurumlarında Okuyan Yabancı Uyruklu Öğrenci Dağılımının Analizi: Mersin Üniversitesi Örneği [Analysis of the Distribution of Foreign Students Studying in Higher Education Institutions: The Case of Mersin University]. International Congress of Management, Economy and Policy (ICOMEP'20), 5-6 December, 2020 Proceedings Book (pp. 132-144). 
Enterieva, M. \& Sezgin, F. (2016). Türki Cumhuriyetlerden Türkiye'ye gelen Yükseköğretim Öğrencilerinin Akademik ve Sosyal Beklentilerinin Karşılanma Düzeyi [The fulfilment level of Turkic Republics higher education students' academic and social expectations in Turkey]. Journal of Higher Education and Science, 6(1), 102-115. https://doi.org/10.5961/jhes.2016.147

Erdoğan, S., Nahcivan, N., \& Esin, M. N. (2014). Nitel Araştırmalar. Hemşirelikte Araştırma, [Qualitative research. Research in nursing], Istanbul, Nobel Tıp Kitabevi, 133-145.

Ertürk, Y. E., Beşirli, H. \& Dursun, T. (2004). Türk cumhuriyetleri öğrencilerinin Türk dünyasına bakışları [Perspectives of students of Turkish republics to the Turkish World]. Ankara, Siyasal Kitabevi.

Foronda, C. L. (2008). A concept analysis of cultural sensitivity. Journal of Transcultural Nursing, 19(2), 207-212. https://doi.org/10.1177/1043659608317093

Günüşen, N. P \& Üstün, B., (2012). Hemşirelik öğrencilerinin klinik eğitimde verilen geribildirime yönelik görüşleri [The perspectives of nursing students about feedback in clinical education]. Anatolian Nursing Health Sciences Journal, 15(3), 197-204.

Jamshidi, N., Molazem, Z., S., Farkhondeh, T. C. \& Kalyani, M. N. (2016). The challenges of nursing students in the clinical learning environment: A qualitative study. Scientific World Journal, 1846178.

Jirwe, M., Gerrish, K. \& Emami, A. (2010). Student nurses' experiences of communication in crosscultural care encounters. Scandinavian Journal of Caring Sciences, 24(3), 436-444. doi: 10.1111/j.14716712.2009.00733.x.

Karataş, Z. (2015). Sosyal bilimlerde nitel araştırma yöntemleri. [Qualitative research methods in the social sciences]. Manevi Temelli Sosyal Hizmet Araştırmaları Dergisi, 1(1), 62-80.

Karataş, Z. (2017). Sosyal bilim araştırmalarında paradigma değişimi: Nitel yaklaşımın yükselişi [Paradigm transformation in social sciences research: Rise of qualitative approach]. Türkiye Sosyal Hizmet Araştırmaları Dergisi, 1(1), 68-86.

Kesten, A., Kıroğlu, K. \& Elma, C. (2010). Language and education problems of international students in Turkey. Kırgızistan Türkiye Manas Üniversitesi Sosyal Bilimler Dergisi, 24, 65-85.

Kıroğlu, K., Kesten, A. \& Elma, C. (2010). Türkiye'de öğrenim gören yabancı uyruklu lisans öğrencilerinin sosyo-kültürel ve ekonomik sorunları [Socio-cultural and economical problems of undergraduate international students in Turkey]. Mersin Üniversitesi Eğitim Fakültesi Dergisi, 6(2), 26-39.

Killam, L. \& Carter, L. (2010). Challenges to the student nurse on clinical placement in the rural setting: A review of the literature. Rural Remote Health, 10(3), 1523. 
Kocabıyık, O. O. (2016). Olgubilim ve Gömülü Kuram: Bazı Özellikler Açısından Karşılaştırma [Phenomenology and grounded theory: A Comparison in terms of Some features]. Trakya Üniversitesi Eğitim Fakültesi Dergisi, 6(1), 51-66.

Kocabıyık, O. O., Donat, S. B. \& Güvendir, M. A. (2019). Yükseköğretimde Öğrenim Gören Uluslararası Öğrencilerin Sorunları [The problems of international students studying in higher education]. Journal of Human Sciences, 16(2), 561-581. doi:10.14687/jhs.v16i2.5455.

Lundberg, P. C., Bäckström, J. \& Widén, S. (2005). Caregiving to patients who are culturally diverse by Swedish last-year nursing students. Journal of Transcultural Nursing, 16(3), 255-262. doi:10.1177/1043659605274952

Ma, A. X., Griffin, M. T., Quinn, C., Katie, L. \& Fitzpatrick, J. J. (2010). Demands of immigration among Chinese nurses. International Journal of Nursing Practice, 1, 443-53. doi:10.1111/j.1440172X.2010.01868.x

Maier-Lorentz, M. M. (2008). Transcultural nursing: Its importance in nursing practice. Journal of Cultural Diversity, 15, 37-43.

Malekisanimaleki, R. \& Altay, B. (2017). Ondokuz Mayıs Üniversitesi'nde öğrenim gören yabancı uyruklu öğrencilerin sosyal destek ve yalnızlık düzeyleri ile kaygı durumlarının belirlenmesi [The determination of social support and livestock levels of foreign students who have studied in Ondokuz Mayıs University]. Ankara Sağlık Bilimleri Dergisi, (1-2-3), 71-96.

Moyce, S., Lash, R., \& Siantz, M. L. de L, (2016). Migration experiences of foreign educated nurses: A systematic review of the literature. Journal of Transcultural Nursing, 27(2), 181-188. doi:10.1177/1043659615569538

Narouz, L. I. (2018). Challenges and culture shock symptoms among international nursing students at Cairo University. IOSR Journal of Nursing and Health Science (IOSR-JNHS) 7(4), 58-66. doi: 10.9790/1959-0704055866 www.iosrjournals.org 58

Okougha, M. \& Tilki, M. (2010). Experience of overseas nurses: The potential for misunderstanding. British Journal of Nursing, 19(2), 102-106. doi:10.12968/bjon.2010.19.2.46293

Özçetin, S. (2013). Yükseköğrenim Gören Yabancı Uyruklu Öğrencilerin Sosyal Uyumlarını Etkileyen Etmenler [The factors that affect foreign university students' social adaptation]. Master's Thesis, Turkey; Hacettepe University Institute of Social Sciences.

Polat, D. C. \& Akcan, E. (2016). Hemşirelik Öğrencilerinin Yabancı Uyruklu Hastalara Bakım Vermede Yaşadığı Güçlükler [Difficulties experienced of nursing students who give care to foreign patients]. Anatolian Nursing Health Sciences Journal, 19, 9-13. 
Polat, Ş. Erkan, H. A. Çınar, G. \& Afşar D. L. (2018). Bir Üniversite Hastanesinde Klinik Uygulama Yapan Öğrenci Hemşirelerin Uygulama Alanlarına Yönelik Görüşleri [Opinions of student nurses practicing in clinics of a university hospital about their fields of application]. Journal of Health and Nursing Management, 5(2), 64-74.

Rienties, B. \& Tempelaar, D. (2013). The role of cultural dimensions of international and Dutch students on academic and social integration and academic performance in the Netherlands. International Journal of Intercultural Relations, 37(2), 188-201. https://doi.org/10.1016/j.ijintrel.2012.11.004

Shawwa, L. A., Abulaban, A. A, Abulaban, A. A, Merdad, A., Baghlaf, S., Algethami, A., Abu-shanab, J. \& Balkhoyor, A. (2015). Factors potentially influencing academic performance among medical students. Advances in Medical Education Practice, 6, 65-75.

OECD. (2016). International students numbers. Retrieved from http://www.oecd.org/education/skillsbeyond-school/EAG2017CN-Turkey-Turkish.pdf

Seviğ, Ü. \& Tanrıverdi, G. (2012). Kültürlerarası hemşireliğin tanımı, amacı, önemi ve tarihsel gelişimi. Kültürlerarası Hemşirelik, 1. Baskı. İstanbul, İstanbul Kitabevi, ss.109-114.

Sezgin, A. A. \& Yolcu, T. (2016). Göç ile gelen uluslararası öğrencilerin sosyal uyum ve toplumsal kabul süreci [Social cohesion and social acceptance process of incoming international students]. Humanitas, 4(7), 417-436.

Sherman, R. O. \& Eggenberger, T. (2008). Transitioning internationally recruited nurses into clinical settings. Journal of Continuing Education in Nursing, 39(12), 535-44. https://doi.org/10.3928/00220124-20081201-03

Small, L. \& Pretorius, L. (2010). Foreign nursing students: Their profile and perceptions of nursing care in Namibia. Journal of Interdisciplinary Health Sciences, 15(1), 1-8.

Stimpson, J. \& Martin, K. (2005). Cultural perceptions of Finnish nursing students regarding people and nurses of the United States: A pilot study. Journal of Transcultural Nursing, 16(1), 64-70. doi: $10.1177 / 1043659604270961$.

Şahin, M. \& Demirtaş, H. (2014). Üniversitelerde yabancı uyruklu öğrencilerin akademik başarı düzeyleri, yaşadıkları sorunlar ve çözüm önerileri [Academic success levels of foreign students at universities, their problems and solutions]. Milli Eğitim Dergisi, 43(204), 88-113.

Tanrıverdi, G. Okanlı, A., Şıpkın, S., Özyazıcıoğlu, N. \& Akyıl, R. (2010). The evaluation of the cultural differences experienced by nursing and midwifery students in nursing. Dokuz Eylul University EJornal of Nursing Faculty, 3, 117-122. 
Taşcı, S. (2012). Sağıık ve hastalığı etkileyen kültürel faktörler. Editor's: Seviğ Ümit, Tanrıverdi, G., Kültürlerarası Hemşirelik. İstanbul Tıp Kitabevleri. 1. Baskı, 19-44.

Tong, A., Sainsbury, P., \& Craig, J. (2007). Consolidated criteria for reporting qualitative research (COREQ): A 32-item checklist for interviews and focus groups. International Journal for Quality in Health Care, 19(6), 349-357. doi:10.1093/intqhc/mzm042

Tortumluoglu, G., Okanli, A., Ozyazicioglu, N., \& Akyil, R., (2006). Defining cultural diversities experienced in patient care by nursing students in Eastern Turkey. Nurse Education Today, 26(2), 169-175. doi:10.1016/j.nedt.2005.08.008

Tortumluoğlu, G., Okanlı, A., Şıpkın, S., Özyazıcıoğlu, N. \& Akyıl, R. (2007). Sağlık yüksekokulu öğrencilerinin bakım verirken yaşadıkları kültürel deneyimler ve etkileyen faktörler. T.S.K.II. Ulusal/Uluslararası Katılımlı Hemşirelik Kongresi. 8-11. Mayıs 2007. Dedeman Ski Lodge, Erzurum.

Bahçecioğlu, T., Gülcan, T., \& Dayapoğlu, N. (2017). Hemşirelik öğrencilerinin ve klinik hemşirelerin intörn uygulamasına ilişkin görüşlerinin belirlenmesi [Determining the opinions of clinic nurses and nursing students about internship]. Anatolian Nursing Health Sciences Journal, 20(3), 170-179.

Tuzcu, A. (2014). Personal problems experienced by the students of nursing in a migrant receiving Province of Antalya and their problems during providing care to migrants in the application area. International Journal of Human Sciences, 11(1), 535-550.

Tuzcu, A. \& Bademli, K. (2014). Göçün psikososyal boyutu [Psychosocial aspects of migration]. Current Approaches in Psychiatry, 6(1), 56-66. doi: 10.5455/cap.20130719123555

Türkiye, G. R. (2017). T.C. İçişleri Bakanlığı Göç İdaresi Genel Müdürlüğü Yayınları. Yayın No: 40.

Tiwaken, S. U. Caranto, L. C. \& David, J. J. T. (2015). The real world: Lived experiences of student nurses during clinical practice. International Journal of Nursing Science, 5(2), 66-75. doi: 10.5923/j.nursing.20150502.05

Weaver, M. R. (2006). Do students value feedback? Student process. Evaluation in Higher Education, 31(3), 379-394. https://doi.org/10.1080/02602930500353061

Xu, Y., Gutierrez, A. \& Kim, S. H. (2008). Adaptation and transformation through (un)Learning: Lived experiences of immigrant Chinese nurses in US healthcare environment. Advances in Nursing Science, 31(2), E33-E47. doi:10.1097/01.ANS.0000319570.99254.e5 